\title{
Beyond the 'Sham' Critique and the Narrative of Humanitarianism: A Rejoinder to Jochen von Bernstorff
}

\author{
Eyal Benvenisti* and Doreen Lustig**
}

We are very grateful to Professor von Bernstorff for taking the trouble to read and comment on our article, ${ }^{1}$ which is a segment of a larger research project. His feedback will be invaluable in taking this project successfully to its next stage. While we could not address each and every aspect of his critique, the following response addresses four elements: the assertion that we argued that international humanitarian law (IHL) is merely a sham; his description of our historical approach as focused on the domestic; the ramifications of our historical analysis for future interpretation of IHL; and the challenge of one's Vorverständnis to historical research.

\section{Beyond the 'Sham' Critique}

Professor von Bernstorff's title "Is IHL a Sham?" implies that our article sought to inquire whether IHL is a sham or argued that it is a sham. His reading situates our contribution among 'scholarly trends' that 'reduce[s] historical narratives on the development of international law to domestic contexts' and that refer to IHL as 'legitimiz[ing] excessive violence instead of mitigating or prohibiting it.' While this sounds critical at first glance, his piece goes on to endorse the narrative he assigns to us by identifying 'four de-humanizing discursive strategies ... which haunt international humanitarian law-making until today. ${ }^{2}$

We believe Professor von Bernstorff's reading is actually somewhat at odds with our argument and historical approach. True, others have argued before, as we mention in the article, that international humanitarian law was - and still is - tailored to legitimize the exercise of violence by governments. But the puzzle we wished to tackle in our article is why governments opted to turn to international codification at that point in history? The approach von Bernstorff defines as the 'sham' approach cannot answer this question. It only emphasizes how the law was ultimately meant to serve the powerful. It does not tell us the reasons for turning to law and international law in this particular moment in history.

Rather than conceiving this history as merely one of power relations between weaker and stronger states, our argument pierces the sovereign veil of states and considers how tensions between governments, elites, and the broader public influenced the history of the laws of war. We endeavoured to shed light on the relevance of social, economic and political processes across

\footnotetext{
* Whewell Professor of International Law and Director of the Lauterpacht Centre for International Law, University of Cambridge; C.C. Ng Fellow of Jesus College, Cambridge, United Kingdom; Visiting Professor, Hebrew University of Jerusalem, Israel. Email: eb653@cam.ac.uk.

** Senior Lecturer, Tel Aviv University, Israel. Email: lustigd@post.tau.ac.il.

1 Benvenisti and Lustig, 'Monopolizing War: Codifying the Laws of War to Reassert Governmental Authority, 1856-1874', 31 European Journal of International Law (EJIL) (2020) 127. Von Bernstorff, 'Is IHL a Sham? A Reply to "Monopolizing War" by Eyal Benvenisti and Doreen Lustig', in this issue, XXX.

${ }^{2}$ Von Bernstorff, supra note 1 , at XXX.
} 
different European societies (such as the rise of nationalism, democratization, or technological advancements) to the codification of the laws of war in that particular moment in history. When von Bernstorff presents our argument as focusing on the 'stabiliz[ation of] the internal political orders against socialist and nationalist movements', ${ }^{3}$ he does not fully capture our explanatory framework that emphasizes the transnational feature of these processes of democratization and deliberately blurs the line between the national and the international.

Furthermore, the comment lumps together our analyses of the 1856 Paris Declaration, the 1864 Geneva Convention, the 1868 St Petersburg Declaration, and the 1874 Brussels Declaration under a unitary explanation, without due attention to the specific context, circumstances and timing of each of these projects and the distinctions we highlighted between the content and role of each of these legal 'events' in the emergence of the international codification of the laws of war during this period. Our emphasis is not merely on nationalist or socialist movements but on how democratization processes in this formative period (1856-1874) set in motion civil society initiatives that reverberated in the battlefields of Europe. Professor von Bernstorff takes issue with our decision to focus on the second half of the nineteenth century rather than on its earlier part. But it was that second half that saw democratic processes, nationalism and rising transnational civil society pressure collide, necessitating a concerted elite effort through international law.

To clarify, the thrust of our argument is that the codification process of this era epitomized a struggle over the role and influence of civil society in Europe. We describe three dimensions of this struggle. First, we consider the contribution of civil society initiatives as an important catalyst for the intergovernmental codification of the laws of war. Second, the institutional dimension refers to the identity of the agents involved in the codification process. The signing of the 1864 Geneva Convention would be the last occasion during the nineteenth century on which civil society activists would be permitted to set the agenda and initiate codification in the context of the laws of war. Our analysis demonstrates how, from the St Petersburg Declaration onward, governments would pre-empt civil society initiatives and exclude their members from participation in the drafting processes. The tension between civil society initiatives and the governmental quest to monopolize the codification of the laws of war would become explicit in the preparations for the Brussels meeting of $1874 .{ }^{4}$ The Conference participants agreed at the outset that only state representatives would take part, ${ }^{5}$ and their deliberations were supposed to be confidential (indeed, they would have remained so had they not been leaked to Leon Gambetta). ${ }^{6}$ Since civil society posed a threat to the governmental monopoly over international regulation and codification, the

\footnotetext{
${ }^{3}$ Ibid., at XXX.

4 The immediate precursor to the Russian invitation to Brussels was a proposal of a French 'International Society for the Amelioration of the Condition of POWs', with which Henry Dunant was associated. See Benvenisti and Lustig, supra note 1, at n. , 175.

${ }^{5}$ Brussels Conference Protocols 3, 14-15.

6 The German Ambassador to Belgium believed someone in the French Government had leaked the protocols to Gambetta, who published them in his journal La République Française. Letter from Friedrich von Perponcher-Sedlnitzky, German Ambassador to Belgium, to Bernhard von Bülow, State Secretary of the Foreign Office (24 August 1874) (folder R 901/ 28963 No. 8, the German Foreign Office, National Archives in Berlin).
} 
turn to inter-state international law-making was meant, inter alia, to assist governments in securing their authority as the sole regulators in the international terrain (and at the same time consolidate their power domestically). ${ }^{7}$

The third and final dimension is substantive and addresses the content of the law. We analyse the content of that codification and demonstrate how it veered away from humanitarian sensibilities. We also show that the substantive dimension was shaped by developments in the second half of the nineteenth century that transformed wars into national events. These processes compelled governments to address the calamities of war through law, as negotiated in Geneva, St Petersburg and Brussels. Yet, governments did not reach agreement on significant constraints on the exercise of violence, either in 1864, 1868 or 1874. For example, Professor von Bernstorff seeks to redeem humanitarian sentiments at the Brussels Conference as he suggests that Brussels adopted a 'bright line rule' for protecting civilians. ${ }^{8}$ Indeed, the Brussels Declaration did prohibit the bombardment of undefended towns and it also protected undefended 'buildings dedicated to art, science, or charitable purposes, hospitals ...' (Art. 17). But, significantly, a 'bright line rule' that would have protected undefended civilian neighbourhoods within defended towns by explicitly classifying them as non-military targets was rejected. We had considered many of these points to already be embedded in our own analysis, but we will certainly make sure to bring them out more clearly in the future.

\section{Beyond the Domestic Approach to Historical Critique}

Von Bernstorff understands our article as claiming that 'IHL primarily served domestic antirevolutionary purposes" ${ }^{9}$ - in other words, that it was designed to strengthen militaries against internal uprisings. But monopolizing warfare was not only about suppressing rebellions. It was also concerned with restraining extreme nationalistic fighters who refused to accept the domestic diktat to surrender, as happened twice during the Franco Prussian war; protecting the resources of the ousted government during occupation against its own citizens, who might try to seize the opportunity to secede (as happened in Belgium in 1916); and ensuring that the government was the exclusive representative of the state in the international arena. In short, through the codification of the laws of war, the European governments were able to entrench their sovereignty externally and also internally.

Von Bernstorff finds it '[s]omewhat surprising that a contribution that interprets the move to codification in IHL as a re-assertion of governmental authority in an age of civil unrest and revolutions makes so little of the contemporary international legal regime of civil wars. ${ }^{10}$ In fact, we address this point directly. We describe the demise of that legal regime of civil wars, which occurred during these formative years of codification (and not, as von Bernstorff argues, after World War II). We demonstrate why the codifiers' explicit agreement to ignore civil wars, thereby

7 For further discussion on this dimension, see Lustig, 'Toward a History of Grassroots International Law: Was the Road Taken?' (on file with author).

${ }^{8}$ Von Bernstorff, supra note 1 , at XXX.

${ }^{9}$ Ibid., at XXX.

${ }^{10}$ Ibid., at XXX. 
leading to the desuetude of the laws on civil wars, constitutes another piece of the puzzle that we examine.

The comment further states: 'A historical focus on the domestic politics of one or two powerful nations also only tends to underrate the influence of coalitions of opposing smaller states on multilateral norm-creation processes. ${ }^{11}$ We couldn't agree more. We address in some detail the positions of weaker governments and the attempts of non-governmental organizations and actors to influence the course of negotiations. We similarly concur and sought to demonstrate how ' $\mathrm{t}] \mathrm{he}$ Brussels Protocol [sic] ... was decisively shaped by numerous diverging interests.' Yet, according to von Bernstorff, most of these interests were 'of a military or foreign policy nature and were not primarily related to potential or past internal rebellions.' ${ }^{12}$ Here we shall have to agree to disagree. This statement, which appears to convey the common wisdom, misses the central jurisprudential point of our argument. We sought to show how 'foreign policy' is shaped by power relations between states (weak and powerful) and within states as well as by coalitions between different segments in these societies. These inter- and intra-power relations informed military considerations and foreign relations and were relevant for international conflicts when citizens refused their government's surrender.

\section{Beyond History, Toward Interpretation}

In our Conclusion, we say that 'this article is meant to help us better understand the past and, in doing so, shed light on the meaningful efforts to insert humanitarian values into the interpretation of the laws of war.' 13 In a future publication, we elaborate on this last point, arguing that understanding the origins of these texts, which grant priority to military necessity over humanitarian concerns, adds weight to David Luban's call for the 'civilianization of the laws of war' ${ }^{14}$ and supports the law-making function of international courts, which Theodor Meron has characterized as 'the humanization of humanitarian law.' ${ }^{15}$ Our history of the laws of war exposes the turn to international law as a countermajoritarian project, and this arguably authorizes -in fact, requires - the judicious interpreter (a domestic or international judge applying IHL) to adopt a critical attitude toward existing treaties and to take into account the interests of the underrepresented in the process of construing it. ${ }^{16}$ Indeed, while the humanitarian language that was inserted into those legal texts was divorced from genuine intentions, it would subsequently be adopted by judges in later generations to interpret the law to serve humanitarian goals. While some

${ }^{11}$ Ibid., at XXX.

12 Ibid., at XXX.

${ }^{13}$ Benvenisti and Lustig, supra note 1, at 169.

${ }^{14}$ Luban, 'Military Lawyers and the Two Cultures Problem', 26 Leiden Journal of International Law (2013) 315.

${ }^{15}$ Theodor Meron, 'The Humanization of Humanitarian Law', 94 American Journal of International Law (2000) 239.

${ }^{16}$ For a domestic analogy to this method of interpretation, see, e.g., Eskridge, 'Politics without Romance: Implications of Public Choice Theory for Statutory Interpretation', 74 Virginia Law Review (1988) 275; Eskridge and Ferejohn, 'Structuring Lawmaking to Reduce Cognitive Bias: A Critical View’, 87 Cornell Law Review (2002) 616. 
have expressed concern about judicial activism and countermajoritarianism, the story this article reveals suggests that the latter was already present at the birth of the codification efforts. Against this backdrop, judicial interpretation that endorses the humanitarian aspects in these sources might prove more democratic than the original elitist formation of the laws of war.

\section{Beyond One's Vorverständnis}

Ultimately, von Bernstorff reflects on the 'inevitable temptation' in historical works 'to assimilate historical evidence into one's own Vorverständnis (prior understanding) of a certain era, or into a grand narrative. ${ }^{17}$

As Ludwig Wittgenstein observed, this is true for every human experience: what we see depends on our prior perceptions. To make this point, Wittgenstein described the two ways we see a cube: '(If I fix my eyes first on the corners a and only glance at b, a appears in front and b behind, and vice versa.) ${ }^{18}$

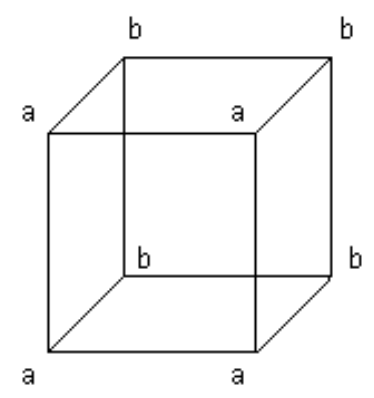

Our tendency as scholars - driven by vocation rather than temptation - is to always question our Vorverständnis: perhaps what we see is what we have been told to see?

Indeed, we have been taught, and we teach our students, that IHL is designed to protect civilians from harm. Others offered a realist critique. In this article, our aim was to question both these perceptions and reevaluate the meaning of the emergence of the international codification of the laws of war by investigating the political, economic and social circumstances that prevailed in the European states that took an active part in the codification process. Our findings offer a different way of looking at IHL, beyond the 'sham' critique or the narrative of humanitarianism. To paraphrase Wittgenstein: if you fix your eyes first on the domestic and only glance at the international, what will appear will be a law that protects governments from civil society challenges.

${ }^{17}$ Von Bernstorff, supra note 1, at XXX.

${ }^{18}$ L. Wittgenstein, Tractatus Logico-Philosophicus (1922), at 72. 